\title{
C-C Motif Chemokine 13
}

National Cancer Institute

\section{Source}

National Cancer Institute. C-C Motif Chemokine 13. NCI Thesaurus. Code C28726.

C-C motif chemokine 13 (98 aa, $\sim 11 \mathrm{kDa}$ ) is encoded by the human CCL13 gene. This protein is involved in leukocyte chemotaxis and inflammation. 